\title{
The beautiful infant and Israel's salvation
}

\begin{tabular}{|c|}
\hline $\begin{array}{l}\text { Author: } \\
\text { James A. Loader } 1,2,3\end{array}$ \\
\hline $\begin{array}{l}\text { Affiliations: } \\
{ }^{1} \text { Faculty of Theology, } \\
\text { University of Vienna, } \\
\text { Austria }\end{array}$ \\
\hline $\begin{array}{l}{ }^{2} \text { Faculties of Humanities } \\
\text { and Theology, University of } \\
\text { Pretoria, South Africa }\end{array}$ \\
\hline $\begin{array}{l}{ }^{3} \text { Department of Old } \\
\text { Testament and Ancient } \\
\text { Near Eastern Studies, } \\
\text { University of South Africa, } \\
\text { South Africa }\end{array}$ \\
\hline $\begin{array}{l}\text { Note: } \\
\text { Prof. James Alfred Loader } \\
\text { is Professor Extraordinarius } \\
\text { at the Faculties of } \\
\text { Humanities and Theology, } \\
\text { University of Pretoria, and } \\
\text { at the Department of Old } \\
\text { Testament and Ancient } \\
\text { Near Eastern Studies, } \\
\text { University of South Africa, } \\
\text { South Africa. }\end{array}$ \\
\hline $\begin{array}{l}\text { Correspondence to: } \\
\text { James Loader }\end{array}$ \\
\hline $\begin{array}{l}\text { email: } \\
\text { james-alfred.loader@univie. } \\
\text { ac.at }\end{array}$ \\
\hline $\begin{array}{l}\text { Postal address: } \\
\text { Dr. Karl-Lueger-Ring 1, } \\
1010 \text { Wien, Austria }\end{array}$ \\
\hline $\begin{array}{l}\text { Dates: } \\
\text { Received: } 12 \text { July } 2010 \\
\text { Accepted: } 15 \text { July } 2010 \\
\text { Published: } 07 \text { June } 2011\end{array}$ \\
\hline $\begin{array}{l}\text { How to cite this article: } \\
\text { Loader, J.A., 2011, 'The } \\
\text { beautiful infant and Israel's } \\
\text { salvation', HTS Teologiese } \\
\text { Studies/Theological Studies } \\
67(1), \text { Art. \#913, } 9 \text { pages. } \\
\text { DOI: } 10.4102 / \text { hts.v67i1.913 }\end{array}$ \\
\hline
\end{tabular}

(C) 2011. The Authors. Licensee: OpenJournals Publishing. This work is licensed under the Creative Commons Attribution License.
The motif from the Exodus story of Moses as a beautiful infant is considered on several levels. Firstly, the immediate context of Exodus 2 in the Hebrew Bible and in the Septuagint is investigated. Exodus 2 is then related to the reception of the tradition in the New Testament and Jewish sources as well as in a patristic reading and one from the Reformation. The article concludes that the motif of Moses' beauty is part of a relatively infrequent but nevertheless well-established constellation. It is submitted that this finding contributes to a reappraisal of the idea that the motif of beauty has no place in Israel's texts of deliverance and an investigation of the contrary hypothesis is called for.

\section{Introduction}

As prominently as the story of Moses' birth features in recent Pentateuchal studies (see Schmid 1999; Gertz 2000; Otto 2000, 2006) and in the extensive monograph by Gerhards (2006), so underestimated the motif of the infant's beauty seems to be. Despite the fact that not only the mental but also the physical features of heroes constitute an established element in heroic narratives of almost all cultures (Heinzle 2007:21), little attention seems to be paid to this feature built into the very beginning of the Moses story. This in itself is surprising in light of the fact that the motif is noticed and highlighted in both Jewish and Christian receptions of the story. In Hellenistic Jewish as well as rabbinic texts on the one hand and in the New Testament as well as patristic and Reformation writings on the other, there are attempts to come to terms with the motif. The mention of Moses' beauty is clearly seen as such a striking feature that it cannot be overlooked.

It is tempting to relate this scholarly reluctance in Old Testament studies to the view put forward at length by Westermann, notably that the motif of beauty is lacking in what he calls Old Testament 'texts of deliverance'. Westermann (1984) puts it as follows:

Where God's saving acts are spoken of and where God's judgement is announced or reported, there is no mention of beauty. This needs no explanation. In the cases of the deliverance ${ }^{1}$ from Egypt, the journey through the desert, the acquisition of the land, the battles during the time of the Judges, the cases where the Prophets announce judgment, where ruin is described, and in the laments on the afflictions of the nation - in all of these words about the beautiful have no place. The same applies to the whole complex of speaking about judgment and salvation in the life of individual people. This is founded on the fact that beauty can have no essential meaning for an Old Testament theology that regards the essence of what happens between God and humans, God and nation, and God and the world only in terms of salvation and judgment - and is therefore strictly soteriological.

(Westermann 1984:120)

The threefold denial of the importance and even the mentioning of the beauty motif in these texts is so categorical that it must have a deep-seated motivation in Westermann's thinking. In my opinion this view is a necessary consequence of what can be called his double-axis theology, according to which the historical line of Israel's salvation history is intersected by the nonhistorical poetic line (Westermann 1992; cf. Dell 2010:60-61). The former represents salvation and deliverance and the latter represents creation and blessing. This is made all the more topical by the fact that Westermann's quoted statement becomes quite sweeping by virtue of the fact that he thinks it valid for such extensive stretches of text in the Old Testament. It could be argued that this goes far beyond what is warranted by the texts themselves.

I now propose to zoom in to one specific text in order to test the validity of Westermann's farreaching claim. The result could warrant a fuller investigation of beauty as a motif in the Old Testament. The initial chapters of the Exodus narrative present themselves as an obvious starting point, because here the story par excellence of Israel's deliverance begins.

\section{The infant Moses in Exodus 2}

The story of the birth of Moses is actually rather a story of his abandonment² (cf. Särkiö 1998:55;

1.Here Westermann uses the German term Errettung [deliverance], not Befreiung [liberation]

2.This designation has been used at least since the middle of the 19th century, when it was used by Theodor Mommsen for the Roman 
Gerhards 2006), which paradoxically achieves his survival. The Pharaoh's command to kill all newborn Israelite males by casting them into the Nile (Ex 1:22) is followed by the story of the birth of Moses (Ex 2:1-10). A man from the 'House of Levi' takes a woman from the same tribe, who bears a son and hides him for a few months. When that is no longer possible, she abandons him by the Nile in token obedience to the king's command, but in a basket. He is watched over by his elder sister, found by the Pharaoh's daughter, adopted and, at the suggestion of his sister, weaned by his real mother. The passage, existing as it does of three units focusing on, respectively, Moses' birth and abandonment (vv. 1-4), the saving of his life (vv. 5-8) and his weaning (vv. 9-10), is relevant to our present purposes on account of the first section, particularly verse 2 .

\section{The Hebrew text of Exodus 2:1-4}

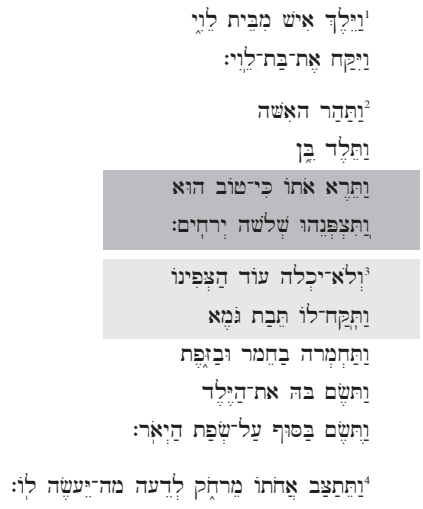

${ }^{1}$ And a man of the house of Levi went

and took a daughter of Levi.

${ }^{2}$ And the woman conceived

and she bore a son.

And when she saw that he was beautiful,

she hid him three months.

${ }^{3}$ But when she could no longer hide him,

she took an ark of rushes for him,

and she daubed it with asphalt and pitch,

and put the child in it,

and laid it in the reeds by the river bank.

${ }^{4}$ And his sister stood afar off, to know what would be done to him.

The famous Assyrian Legend of Sargon (see Gerhards 2006:170-177 for Neo-Assyrian text, transcription and German translation with notes) from the eighth century BCE (Gerhards 2006:179) shows several parallels with this passage: The baby is conceived by an unknown or unnamed father, hidden, laid in a basket of rushes and put in a river or on a river bank; he is found and adopted and finally rises to prominence. Whether the father is mentioned in such a way as to warrant Otto' $\mathrm{s}^{3}$ interpretation of an extramarital or illegitimate birth may be disregarded for our present purposes, important though it is in its own right (Schmid 1999:154; cf. Otto

(Footnote 2 cont...)

legends of Romulus and Remus and in critical literature the technical term used is Aussetzungsgeschichte, that is, 'abandonment story'.

3.Otto (2000:49, 2006:38) bases the argument on the observation that verse 1 in ou text uses the verb לקח לאשה without the intransitive object, which is always used when the verb is used to mean 'taking a wife'.
2000:49, 2006:38; contra Blum 2002:145; Gerhards 2006:27). However, that is not the case with his interpretation of the intention of the text. According to Otto (2000:58, 2006:39), the story of Moses' abandonment is a subversive reception of the Sargon story in that it makes Moses the antitype of the Assyrian king. In principle, confirming Otto's thesis, Gerhards (2006:250-253), however, interprets the narrative as an exilic story of hope (Gerhards 2006:253-264). On both counts the narrative acquires considerable religious impact, defining as it does Israel's spiritual leadership in opposition to that of Mesopotamia and/or restoring hope of deliverance to the exiles in Mesopotamia.

Apart from details about the construction of the basket and the presence of the sister, there is a motif in the Exodus passage that is highlighted both by the strong religious intention and by a fact that it is lacking in the Assyrian story. This is the reference in verse 2 to the baby's beauty. That the beauty motif is important is supported not only by the two aspects just mentioned but also and particularly by the formulation of verse 2 and its unexpected logical impact.

Of the twelve sentences in the abandonment passage (vv. $1-4)$, all but one contain the waw consecutive with imperfect third person feminine singular. The exception is verse $3 a$. But it is only an exception because a negative formulation, which calls for ולא plus perfect, is required here.

This unit consists of four complete waw imperfect sentences at the beginning and four at the end. In the middle are two paratactic constructions (vv. $2 b$ and $3 a$ ):

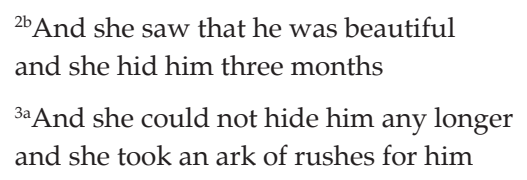

In verse $3 a$ the second clause is the main one and the first is the paratactic expression of a temporal clause: 'when she could not ... then she took' ${ }^{4}$ In verse $2 \mathrm{~b}$ the second clause is also the syntactical main clause, whilst the first is the paratactic formulation of a substantiating adverbial clause: 'because she saw that he was beautiful, therefore she hid him ...'.5 An alternative possibility for verse $2 b$ is that the paratactic construction may be taken as circumstantial (Gesenius \& Kautzsch 1966:\$156a), which would entail the same logic: The circumstances being that the baby was beautiful, she decided to hide him. ${ }^{6}$ That would mean that she would not have hidden him if the circumstances were different, which is to say she would have allowed her ugly baby to be drowned in the Nile. In turn, that would make nonsense of the culturally universal expression that an ugly face is one that only a mother can love. The saving of the infant's life

\footnotetext{
4.Gesenius and Kautzsch (1966:§164b [1]): the use of two imperfects consecutive as the first of five variations (with examples).

5.Gesenius and Kautzsch (1966:\$158a): A causal relationship between two complete clauses may be expressed by w or even without the conjunction (e.g. Gn 17:14b).

6.Gesenius and Kautzsch (1966:\$142d), where similar illustrations are given, for example Genesis 18:17-18: God will reveal his plan to Abraham, seeing that he will become a great nation. That is, because of the fact that Abraham will become a great nation, God will reveal his plan to him.
} 
is therefore dependent on his being beautiful, which, again, means that his beauty is the cause of his life being saved.

This cuts in two directions. Firstly, the dilemma of having to ascribe an extremely embarrassing ethical attitude to Moses' mother becomes apparent. Substantiating the attempt to save her child by the fact that he was beautiful would mean that she was prepared to let him be killed if he were not. Even the emergency premise that טוב hust mean 'well formed' would not absolve her. A mother prepared to let her baby be drowned because he does not seem all too healthy would deserve the same censure, if not more severe. Therefore, later Jewish exegesis had to go to considerable lengths to explain the problem away, as we shall see below. Secondly, the very inconceivability of this suggestion points in another direction. There must be a well-founded reason for linking Moses' deliverance from death by the Egyptians to his beauty. There seems to be a hole in the narrative. Is the answer not perhaps to be sought in taking the literary mode of the narrative seriously? Put another way, is it perhaps possible that we here have a literary trope linking beauty with deliverance?

It is clear that in this story Moses' own personal deliverance is interlocked with his being beautiful. Even if the construction is taken as built on a circumstantial clause, that is still the case. Considering that this happened in the personal life of the greatest leader in Israel's history of deliverance forces the question whether this is not perhaps a miniature with more extensive parallels in the Old Testament. This seems plausible prima facie, as the story of the exodus begins here and the rest of the story book is dependent on what happens here. At any rate, the sweeping nature of Westermann's claim that '... where God's saving acts are spoken of ..., there is no mention of beauty' is already in serious jeopardy by reason of what we have found so far.

But this is not the only reason to call it in question. Before attempting an answer to the question suggested by the beauty of the child and the role of the parents confronted by this beauty, let us first consider some ways in which this passage was received through the centuries.

\section{The Septuagint version}

The Greek version, though remaining fairly near to the Hebrew text, does contain some interesting features at odds with the Hebrew text:

${ }^{1}$ ha de tij elo thi' ful hi' Leii

oil \& aben twh qugaterwn Leai

kai . escen kai . kateskopeuen h' add $f h$. autrou/ nakr ogen naqgi $h$ ti, to. apoldhsonenon autwatuthn

${ }^{2}$ kai . en gastri . el aben

kai . £eken arsen

i dontej de auto. astei on erkepasan auto. nhnhaj treij

${ }^{3}$ eque . de ouk holunanto auto. eti krupte n el aben autw// h' nhthr autow qikin

kai . katecrisen authn asf al topi ssh

kai . exebal en to. pai d on eij authn kai . eqhken authn ej j to. $€$ oj para. ton potanon

${ }^{4}$ kai . kateskopeuen h'add $\mathrm{f} h$. autrou/nakr ogen nagei $h \mathrm{ti}$, to. aprobhsonenon autwl

${ }^{1}$ And there was a man of the tribe of Levi,

who took one of the daughters of Levi

and had her as wife.

${ }^{2}$ And she conceived,

and bore a male child;

and seeing that he was good-looking, they hid him three months.

${ }^{3}$ And when they could no longer hide him, his mother took for him an ark,

and besmeared it with bitumen,

and threw the child into it,

and put it in the marsh by the river.

${ }^{4}$ And his sister looked on from a distance, to learn what would happen to him.

The aspects standing out in a comparison with the Vorlage are the following:

- Here there is no question about the marital status of Moses' parents when they conceived him. The Levite first 'took' [e aben] the woman and then 'had' [escen] her. The verb ecein can mean 'be married' and in this combination cannot mean anything else.

- The Septuagint is at pains to involve Moses' father in the decision to hide him (i dontej and exkepasan in v. 2 are plural) as well as in the actual concealment of the child (hdnanto in v. 3 is plural as well). Where the Hebrew text has only the mother involved in the decision, here the father shares the credit and the ambiguity. However, the mother does the abandoning alone (the rest of the verbs after this are all third person singular). She shows no maternal affection when she chucks the baby into the basket and then dumps him in the marshland by the river bank, where crocodiles are a greater danger than the fastflowing midstream. The harsh expression 'she threw the child into the basket' ([eaebal en], v. 3b) at least casts doubt on the mother's attitude towards her infant son.

- Verses 2-3 of the Tanach, interpreted above to have the Hebrew equivalents of subordinate clauses, are understood precisely so by the Septuagint. In verse 3a the two clauses are hypotactically related to form a compound sentence with the main clause at the end and its subordinate, the ader bial equ-clause, at the beginning: 'when they could no longer hide him, his mother took $\ldots$... In verse $2 b$ the paratactic construction of the Hebrew text is also collapsed into a single compound sentence, in this case by means of the participle idontej, 'seeing'. The participial clause, like its equivalent in the Hebrew text, can be taken as a circumstantial clause, which has the same effect as in the Vorlage, making Moses' survival dependent on his looks. Alternatively, it could be argued that the use of orawin the participle has the same effect as the English 'seeing that', that is, 'in light of the fact that', again establishing a causal relationship between Moses' physical appearance and his deliverance. If, by seeing them duly married, the Septuagint safeguards Moses' parents against the immorality of having an extramarital 
and therefore illegitimate child, it is to be expected that it would also have grasped the opportunity to eliminate the embarrassment of a questionable motivation for saving the child's life, unless there was a reason for connecting the fairness of the child with his life being saved.

Therefore, on the basis of the Septuagint text (1) the motif of the fair infant and (2) the actions of his parents are heightened by the very ambiguity brought about by the holes of the Hebrew text being made larger. There seems to be good reason to suppose a close association of beauty with redemption.

\section{The infant Moses in the New Testament}

Turning to the New Testament, we find two passages where the reception of the infancy narrative is carried by a strong religious undercurrent.

\section{The speech of Stephen in Acts 7}

Giving a review of Israel's history from Abraham to the monarchy and the latter prophets (Ac 7:2-53), Stephen includes Moses $^{7}$ with prominent reference to his infancy (vv. 19-21):

${ }^{19}$ outoj katasof i sanenoj to. genoj hh̀ ekakwsen touj pateraj îhǹwh' tou/ poi en tha. bref $\mathrm{h}$ ekqeta autwh ejj to. nh. zupgone sqai $\AA$

${ }^{20}$ En w tkai rw/ egennhoh Mmshi

kai . ha astébj tw/qen*

oil anetraf h nhinaj trej' en tw/ oi kw/ tou/patroj (

${ }^{21}$ edtegentoj de autrov/arie | ato autron h 'qugathr Faraw kai . aneqreyato aution eàuth/

${ }^{19} \mathrm{He}$ [the Pharaoh] dealt treacherously with our people and oppressed our forefathers

by forcing them to throw out their newborn babies so that they could not live.

${ }^{20}$ At that time Moses was born,

and he was beautiful to God.

For three months he was cared for in his father's house.

${ }^{21}$ When he was abandoned, Pharaoh's daughter took him and brought him up as her own son.

Several things are noteworthy about the presence of Moses in the speech.

- Firstly, quite in agreement with conventional Jewish views, he occurs prominently as the central figure of the actual liberation of Israel from Egypt (vv. 19-36) and therefore also in the whole speech, as he does in the Tanach itself.

- Secondly, the retelling of the liberation story is opened by an infancy passage practically as long as that in the Book of Exodus and therefore all the more prominent in the short summary that covers the whole history of Israel up to the prophets. The relative proportionality seems to highlight the importance of the baby Moses appreciably, because room for such details in a bird's-eye overview of the religious history of Israel can only be justified by their

7.Johnson (1992:122) probably goes too far in assigning all of vv. 17-53 to a section 'The prophet Moses' to make up the second half of Stephen's speech. Moses features prominently in the section vv. 17-44, which is noteworthy in itself. importance, especially in such a passionate address.

- A third aspect is the way in which Stephen foregrounds Moses' father even more than the Septuagint does: Moses is initially cared for in his father's house without reference to his mother's role in weaning him (v. 20).

- But, in the fourth place, when it comes to his abandonment (v. 21) we do not hear who did it, for the passive formulation (ekteqentoj) softens the embarrassment without apportioning blame. On the one hand, the mother gets off better than in the Septuagint by not being cast in the single active role. More importantly, on the other hand, the function of focusing away from the parents to the baby not only prepares his being cast away but it also suggests that his being found, adopted and educated is attributed to providence. Only God can be the subject of the train of providential events.

- A closer look at verse 20 reveals that the beauty of the infant is enhanced over against both the Tanach and the Septuagint. He is not only beautiful, he is divinely beautiful [asteibj tw/ qewl. The adjective used (asteibj) is the same as the one used in the Septuagint. Whether or not the addition of tw/ qew/' 'unto God', is an intensive expression equivalent to a strong superlative, ${ }^{8}$ its adverbial function obviously reflects the religious nature of Moses' beauty. This must clearly be the case in the light of Stephen's picturing Moses' calling as God's prophet par excellence as well as Stephen's recourse to the often recurring motif of God's beauty in the Old Testament (Ps 27:4; 90:17; Ex 33:18-23; also Is 35:2; Ps 104:1,31; Ps 145:5,12) (cf. Gestrich 2008:92; Loader 2010:17 § 6). He notably refers to the famous passage about the splendour of Moses' shining face, where the attribute of beauty is extensively substantiated by his calling and special relationship with God (Ex 34:29-35). ${ }^{9}$ This too seems to be paralleled in the introduction to the address of Stephen, whose face takes on an angelic complexion as he is presented as God's witness telling the story of Israel (Ac 6:15).

All of this means that the reception of Moses' beauty in the Book of Acts boils down to the following:

- his fair appearance pointed to a divine involvement with this child, which was

- revealed by the events following his parents' abandoning him to have been God's providence working towards the realisation of the plan to save Israel from oppression by the Pharaoh.

\section{The cloud of witnesses in Hebrews 11}

In another tour de force through the Old Testament, the

8.Cf. Genenis 1:2, where Gunkel ([1901] 1969:104) explains אלהים as the element qualifying the noun in the construct state to be that which mysteriously exceeds normal human capacity. Newman and Nida (1972:151) find the 'strong superlative' in verse 20 and in Genesis 10:9 (with יהוה instead of אלהים) as well as in John 3:3.

9.Moses' face is said to 'shine' when he comes from the presence of God (Ex 34:30, 35) on account of the fact the he spoke with God (v. 29). The Hebrew verb 'shine' as denominative of , 'horn' 'ray' is the origin of the Vulgate version 'shine', as denominative of P P , horn', 'ray', is the origin of the Vulgate version cornuta esset facies sua, 'his face had horns' (that is, the 'horns of light') and this in turn inspired Michelangelo's famous depiction of Moses with horns emanatin from his forehead. Cf. also Habakkuk 3:4, where the rays or horns of light are directly associated with God's splendour. A negative view of Moses' veil (not of his beauty) is found in 2 Corinthians 3:13. 
beauty of Moses is again closely related to the actions of his parents. In Hebrews 11 the scope is also vast in that it covers the whole Old Testament. This time it is, however, adeptly terminated by a shortcut in verse 32 , where the author appeals to the universal excuse of not having enough time and only mentions a few representative personages to fill the vacuum he does not treat (somewhat like the filling up of untold story space by name lists in the initial chapters of 1 Chronicles). The relevant text in Hebrews 11:23 is the following:

\section{Piste MmBhil gennhaej edrubh trinthnon ùjo. twh paterwn autrow \\ di oti e e elon asteion to. pai don \\ kai . ouk ef/odhohsan to. d atagna tou/basi l enj}

By faith Moses was hidden by his parents for three months after his birth,

because they saw that the child was beautiful;

and they were not afraid of the king's edict

Here the beautiful infant is again a prominent feature and several particularities contribute to our investigation:

- Moses' abandonment by his parents is totally neglected. Both parents come away with flying colours but not only on account of not appearing as Hansel-and-Gretel-type parents. Their merit dovetails with the main theme of the chapter's 'cloud of witnesses' (Heb 12:1).

- This is formulated clearly in the verse that states that the parents concealed their infant son 'by faith'. To be sure, this is formulated in the passive mood (dkruph, 'he was hidden'), but the logical subject of the passive verb is expressly added: ù̀o. twh paterwn autrou 'by his parents'. As Moses himself through faith later preferred to scorn the pleasures of Egypt and preferred to suffer abuse for Christ's sake and as all of the other heroes of faith in Israel's history did what they did by virtue of their faith, so Moses' parents opted for civil disobedience and saved their baby's life through the very same faith.

- The crux of the matter lies in the seemingly illogical motivation for hiding the child: On the one hand, it says clearly by means of a datious causae ${ }^{10}$ [pistei] that the reason why the parents spared their baby's life was their faith. This incorporates them into the whole list of witnesses from the Old Testament who did what they did because of their faith. The fact that this is inaugurated by a clear Semitism in verse 2, en tauth|(referring to pistij of v. 1) ${ }^{11}$ (Michel 1966:379), confirms the repeated use of the dative piste with this function. On the other hand, the text is just as clear in motivating the decision by the parents' observation, for it states that they concealed him 'because' [d oti] they saw that the infant was beautiful. So they did it because of their faith and they did it because they recognised the infant's beauty. In the context of the whole chapter, where the overriding concern is the power of faith, this cannot mean that they had two incompatible reasons but only that the two factors coincide (cf. below

10.The dativus instrumentalis is closely related to the dativus causae, the forme responding to the question 'whereby?' and the latter to the question 'why?' (cf. BDR § 195-196). This is the conventional shorthand to refer to Blass and Debrunner.

11.This equals the Hebrew $\mathrm{N}$ 'by it' with bet instrumentalis. on Chrysostom, who noticed this).

- Recognising the child's beauty as an act of faith therefore explains their disobedience to the Pharaoh's command and connects smoothly with the rest of the chain.

What could it mean that faith and seeing beauty coincide? I think the author gives us the answer explicitly in his opening verse with its famous definition of faith: Faith is 'the assurance of what we hope for' [elpi zonenmn upostasij pragnatun] and 'the evidence of what we cannot see' [e egcoj ound eponenvn]. Moses had the same vision as his parents. Continuing the Moses theme, the author credits him with liberating Israel from the bondage of Egypt by a faith [pi stei] that persevered against the anger of the king because it could see the unseen (v. 27: ton gar auraton wy or wh ekarterhsen). Therefore (1) the beauty of the infant was a pointer to his divine calling to save Israel by liberating them from the Pharaoh's wrath and (2) this is what his parents could see by their faith.

Our author's reading of Exodus 2:1-10 sits well with both Otto's thesis of defiance against an oppressive king (Heb 11:27) and Gerhards's thesis of a theology of hope (Heb 11:1), but it is diametrically at loggerheads with Westermann's opinion that beauty and redemption do not go together (Heb 11:23). This is not 'reading the Old Testament in the light of the New' but means learning from reception history that we may not today notice all that the ancients have earlier noticed. This may encourage us to cross-check in relevant Jewish sources.

\section{The infant Moses in Jewish texts}

We attend to two Hellenistic texts and a number of rabbinic theologoumena.

\section{Flavius Josephus, Antiquitates Judaeorum II.9.3-7}

Josephus expands the motifs we have found so far to such an extent that they can only be summarised for our purpose.

- The parents of Moses are clearly identified as Amram and Jochebed, who are expressly said to have been married (Ant II.9.4).

- The religious nature of all circumstances preceding, during and after Moses' birth is embroidered upon. Amram is visited in a dream to receive the revelation of what God intends the yet unborn son to do in order to deliver Israel from bondage (Ant II.9.3). In light of the extensive attention to divine involvement, it comes as no surprise to learn that Moses' mother had almost no labour pains at his birth (Ant II.9.4).

- Not only are both the parents involved in saving the child's life and nourishing him but they also do so prayerfully on the grounds of the revelation received. Josephus uses this idea to turn the motif of abandonment into its opposite: Amram decides to entrust the life of the baby to God rather than to run the risk of thwarting God's plan for Moses by trying to achieve the impossible himself. So there is no talk of abandonment but only of faith in God's promise and providence. This is enhanced by a description making it clear that Moses was quite comfortable in his little ark and committed to the main 
current of the river, not just discarded amongst the reeds on the bank. He was carried away by the stream and saved by some of the royal maids who had to swim into the river to fetch the child for the princess. Somehow his sister managed to keep abreast along the bank and cleverly organised the preliminary care of the baby in his parental home (Ant II.9.5).

- The beauty of the infant is profusely described. ${ }^{12}$ God had specifically taken care to make Moses a beautiful baby ${ }^{13}$ so that he would 'be considered worthy of bringing up and being cared for'. ${ }^{14}$ As he became a toddler and grew bigger, he was so beautiful that people would stop only to stare at him (Ant II.9.6). But although this beauty also fascinated his adopted grandfather, the Pharaoh, he, somewhat in terms of Hebrews 11:25-26, scorned the royal crown and was identified as the redeemer foretold by the Egyptian sages themselves (Ant II.9.7), precisely the reason why the Pharaoh had decreed all Hebrew newborn males to be killed (Ant II.9.3). This is closely parallel to the story of the mass infanticide of Bethlehem, perpetrated by royal order to prevent the prophesied birth of a redeemer threatening to the king (Mt 2:1-17).

Although a fanciful narrative is woven out of the traditional materials, the main motifs are all present and accorded the same function as in the texts we have been examining so far:

- The beauty of the infant is seen as the cause for his own survival and therefore of the liberation of Israel, not merely because his parents were fascinated by his pleasing appearance but because God planned his beauty to fascinate the princess so that the process of Israel's redemption could be set in motion.

- His parents even had a revelation to prove that this was a religious matter.

\section{Philo of Alexandria, De Vita Mosis 1.3}

Philo's Life of Moses, as could be expected from its topic, also pays extensive attention to the story of Moses' abandonment:

- As opposed to Josephus, the parents are not exonerated by making them heroes of faith for entrusting their son to God, but they are circumspectly treated. First, Philo praises their moral virtue and counts them 'among the most excellent persons of their time' ${ }^{15}$ They do abandon their baby on the river bank but do so grieving and weeping for what they necessarily have to do in order to avoid a greater disaster to many more people. Honestly taking the blame on themselves and calling themselves the 'killers and murderers' ${ }^{16}$ of their own child, they abandon him for the greater cause of saving more lives. Halfway

12.For the terms used, compare Ant II.9.5, where kal I oj, 'beauty', is used and II.9.6, where kal, I oj as well as qaumastoj, 'wonderful' (with reference to his tallness [amasthma]) and carij, 'pleasant appearance' occur.

13.tosauth| gar o' qeoj peri . Mmushn earchsato spouch... (['God went to such lengths concerning Moses ...'], with reference to his fair appearance).

14.trof h'" kai . eqi nel ej aj akji wohna.

15.twh kaq èutouj ari stun (Vit. Mos. 1.2.7).

16.autocei raj te kai .teknoktonouj (Vit. Mos. I.3.10). between the harshness of the mother in the Septuagint of Exodus 2 and the deep faith of the parents in Hebrews 11, Philo lets them appear ambiguous regarding the abandonment motif: Whereas Stephen's speech bypasses the problem by means of passive formulation, Philo explicitly stresses their morality and thereby the rest of his version can highlight the divine activity in the events.

- Here too the beauty motif is emphatically used to motivate the saving of the infant's life. The parents resolve to hide him because just after his birth they saw that he was 'unusually beautiful' ${ }^{17}$ As in the Josephus text, Philo also uses the motif to motivate the decision of the princess to adopt him. She first takes a good look at the baby 'from head to foot' and is then said to admire his 'elegant form and healthy, vigorous appearance'.$^{18}$ As in Josephus, the beauty motif is extended into the period after his weaning, when he is called 'a fine and beautiful child to behold'. ${ }^{19}$

- Central to the whole drift of the Philo version is the divine purpose at work in the life of Moses, but here it is expressly connected to Moses' beauty: in the context of the princess' deciding to adopt him after observing his perfection and appearance, Philo gives all the credit to God by adding, 'God easily brings to pass whatever he pleases. ${ }^{\prime 20}$ This means that God willed and used the infant's beauty to overcome the Pharaoh's injustice.

- Generally in Philo's writings, Moses' perfections are so lofty that Philo had to ask himself whether Moses was actually divine (Williamson 1989:55-56). In the Vita Mosis the appearance of the infant is integrated so thoroughly with his other perfections that it is not surprising that this question is also answered in this work. In Vita Mosis I.158 Philo goes so far as to call him 'god and king' [qeoj kai. basil aij]. Although this pushes the boundaries for a Jewish perspective, it may be compared to the Old Testament association of the beauty of God and the beauty of the king ${ }^{21}$ (Loader 2010:7, 17; Oeming 2004:961).

So, for Philo too:

- the beauty of the baby is the cause for his life being saved, first by his parents and then by the princess, but only because God had arranged that to reach his own goal of redeeming Israel

- the parents are not said to have done what they did because of their faith, but their morality and willingness to give up their child to prevent a greater disaster put their own actions in a deeply religious context.

\section{Midrash Rabbah Exodus}

A number of rabbinic opinions on Exodus 2:2 show that a century after Josephus and Philo, the rabbis also noticed

17.aste oter an h.katVi whn (Vit.Mos. I.3.9); the same adjective as in the Septuagint version of Ex 2:2, as well as Acts 7:20 and Hebrew 11:23 is used.

18.emorf i an kai eved an(Vit. Mos. I.4.15)

19.eugenh/kai . astei on of/chhai (Vit. Mos. I.5.18).

20.panta d vexumarized ceoj àan eqd hsh (Vit. Mos. I.5.19).

21.On the one hand: 1 Sa 9:2; Ps 45:3; 136:18; on the other hand: Ps 27:4; 104:1, 31; 145:12; (cf. Loader 2010:7, 17 [forthcoming]; Oeming 2004:961). It should also be kept in mind that in the Old Testament itself Moses is what Schmid (1986:54) calls a 'heroic giant' so that he becomes almost godlike (cf. Ex 34:29-35 in connection with the motif of his radiantly beautiful face) 
the motif of beauty and tried to come to terms with it. The Midrash Rabbah on Exodus offers several possibilities dating הווא in Exodus 2:2.22

- According to Rabbi Meir, the parents observed that the infant's name was 'Good'. That would provide a Hebrew alternative for what was perceived as an Egyptian name, but it would also absolve the father and mother from the moral objection that could be levelled against parents that are implicitly willing to let unattractive infants die. On Rabbi Meir's submission, recognising Moses' beauty means recognising that he was to be the one who would do 'good' to Israel, first by liberating them from bondage and then by mediating the Torah to them.

- The variant of this reading, provided by Rabbi Joshiyyah, namely that the baby's name was 'Tobiyyah' [טוביה], adds the theophoric element to the name and can therefore be seen as a strengthening of the religious dimension of the story.

- The third option is proposed by Rabbi Yehudah, טוב refers not to the infant's proper name but to his prophetic aptitude. The parents saw that he was 'good' for prophecy, so they saved him to become the greatest of Israel's prophets.

- According to 'others', the parents saw that he was born 'good' in the sense of circumcised, which points to his extraordinary role as religious leader.

- Still another reading, only ascribed to 'the rabbis', has the house filled with the radiance of light when Moses was born. This reading connects the being טוב Ooses' appearance with the beautiful radiance of light. For this they appeal to Genesis 1:4, according to which God saw that the light was טוב.

- A final possible reading is offered by the Midrash, this time explicitly using the Hebrew adjective to explain טוב ${ }^{23}$ It echoes Josephus's passage claiming that people would stop to stare at Moses' beauty (Ant II.9.6) by stating that all wanted to see him because of his being and, once they saw him, could not tear themselves away from him.

The same tradition, the same motifs and the same thrust of the interpretations encountered in the Septuagint, the Book of Acts, the Epistle to the Hebrews, Josephus and Philo.

\section{Chrysostom and Calvin on the baby's beauty}

John Chrysostom (c. 347-407) as well as John Calvin (15091564) noticed the importance of the motif of Moses' beauty as well as the problem posed by it. Both interpreted the text in a similar way.

\section{ExR 1 (66d)}

23.ExR 1 (67b) The Targum Yerushalmi I circumvents the issue by deducting the three months' concealment from nine months' pregnancy, so that the baby is born three months early but judged for life, in other words capable of surviving.

\section{Chrysostom, Homily XXVI on the Epistle to the Hebrews}

In the second section of his Twenty-Sixth Homily on texts from Hebrews, Chrysostom says the following ${ }^{24}$ :

He [the author] increases consolation by relating the matter to commonplace persons. ... Seeming to be less important than people without as much as a name, that is the important thing. And he begins with Moses' parents, who were people of no consequence ...

Now it is necessary to speak about the parents of Moses ... Whence did they have their hope that the little boy would be saved? - From faith. From which faith? - It says, 'They saw that the child was beautiful'. Even his outward appearance drew them to faith. Therefore this righteous person was from early on, even when he was still in diapers, richly imbued with grace, which was not a gift of nature, but the work of God. For just look: immediately after birth the infant looked beautiful and not ugly. Where does that come from? Not from nature, but from the grace of God, which also roused the foreign Egyptian woman and gave her the strength to take and adopt the infant. However in this case the faith did not have sufficient foundation, for what kind of faith can (only) be deduced from the appearance of a face?

(Hom. Heb. XXVI,2)

Here Chrysostom clearly associates beauty with the grace of God.

- Interestingly, Chrysostom finds the beauty of the infant not so much in an outward mark or aspect (as Calvin does; cf. below) but in the faith of the parents. The outward appearance did draw them to faith, but not of itself. It was due to the grace of God. This grace is imbued in Moses as a power that draws people. The beauty is therefore really in the eye of the beholder, because it was made visible by God's grace. This is interesting, as Chrysostom does not deny the beauty of the child but equates it with a gift of God to draw people towards him.

- The role of the parents is therefore completely dominated by the grace of God that gave them faith. Chrysostom therefore has no moral problem with the motivation for saving the child. It does not suppose that the parents were merely fascinated by outward appearances, they need no defence against the implication that they would have let an ugly child die.

- But he does notice the importance of the anonymity (using the adjective armununoj ) of the insignificant [ashnoj] people who were Moses' parents. That shows that not only the central figures of history but also common people can be heroes of faith by the grace of God.

The motif of beauty and the motif of the parents are given a very interesting meaning in this sermon:

- The beauty of the infant is not only given by God but also consists of an aspect imbued in Moses as well as the ability to recognise it and 'be drawn' by it.

- The parents' ability to recognise this is both grace in itself and a sign that common folk may receive God's grace. ${ }^{25}$

24.Hom. Heb. XXVI,2; I quote only relevant excerpts.

25.The logic of outward form not being important of itself but acquiring meaning through faith as a gift of God's grace shows similarities to Calvin's views on the relationship between the outward form and recognition of the inner meaning 


\section{Calvin, Commentary on the Epistle to the Hebrews}

Coming to Hebrews 11:23 in his Commentary on the Epistle of Paul the Apostle to the Hebrews, John Calvin notes the problem of the parents' motivation for saving the life of Moses. He says the following ${ }^{26}$ :

The Apostle shows that the parents of Moses were inducted to save him for another reason, notably that - as God had promised them under their oppression - there would come some time a deliverer, they relied confidently on that promise, and preferred the safety of the infant to their own.

... doubtless God would not have us to regard what is externally attractive. To this I answer that the parents of Moses were not charmed with beauty, so as to be induced by pity to save him, as is commonly the case among humans, but that there was some kind of sign of future excellence imprinted on the child, which gave promise of something extraordinary. There is, then, no doubt but that by his very appearance they were inspired with the hope of an approaching deliverance; for they considered that the child was destined for the performance of great things.

... We must, however, remark that the faith here praised was weak; for after having disregarded the fear of death, they ought to have brought up Moses; instead of doing that, they exposed him. It is therefore clear that their faith in a short time not only vacillated, but collapsed altogether ${ }^{27}$; at least they neglected their duty when they abandoned the infant on the bank of the river. But it befits us to be even more encouraged when we hear that their faith, though weak, was nevertheless approved by God so as to secure the life of Moses, on which depended the deliverance of the Church.

(Comm. in Heb., ad 11:23)

As opposed to some of the ancient interpretations we have noted, Calvin does not exonerate the parents by putting the abandonment down to trust in God's providence (Josephus); neither does he justify the deed by subordinating it to a greater evil (Philo) or circumvent the problem by using passive a verb (Ac 7:21):

- Instead, he reproaches the parents for first saving the baby and then inconsistently losing faith and abandoning him on the river bank. The silver lining to this is that he, somewhat like Chrysostom, distils comfort from what he regards as proof that even weak faith has a place in the 'cloud of witnesses'. Consequently, his reading contains a nuanced, if artificial, interpretation of the religious motive for saving the infant.

- But the beauty motif poses its moral question for Calvin as well. He notices that the problem of the text in both the New and the Old Testament forces the conclusion that to the parents the infant's beauty was the reason for the saving of his life, which would be wrong if it cannot be explained in another way. This Calvin does in a manner not unlike what we have seen in the Midrash Rabbah: Under the influence of his own theological convictions, he provides an element that is not present in the text: The

(Footnote 25 cont...)

of the elements of the Lord's Supper through faith as a gift of grace. Calvin (see below) knew Chrysostom well but seems to mis the opportunity of analogy here.

26.Comm. in Heb., ad 11:23; I only quote relevant excerpts.

27.Patet igitur illorum fidem brevi non tantum vacillasse sed fuisse collapsam. beautiful thing about Moses must have been some visible aspect of his appearance by which the parents could tell that their deliverance from bondage was near.

So we have the same substructure again:

- the beauty of the infant communicated a special religious sign, namely that a divine mission was to be expected from this child

- even the parents' wavering faith could notice that redemption was near.

\section{Conclusion}

It has been suggested that the New Testament reception of the Exodus text as we have it in the Tanach as well as in the Septuagint agrees with some specialist Old Testament studies and is at loggerheads with others. We have found a long and consistent tradition in which, for all the differences in details, the basic structure is the same up until the dawn of modern biblical scholarship. This in itself but also the fact that the consistency holds water in both Jewish and Christian texts strongly supports the position that we are not confronted with a discrepancy in the Hebrew text that can only be explained away by reading it under the impact of the New Testament. On the contrary, the diverse details and religious purposes for which the interpretations are used testify to a remarkably stable reception history of the fundamental logic of the infancy story. It is therefore justified to conclude that the literary, linguistic and logical reasons proposed above for linking and not separating the motifs of beauty and redemption are not only strong in themselves but also have a large cloud of witnesses around them. That is not yet sufficient to reject Westermann's thesis on beauty in the Old Testament out of hand. But it is justified to judge his failure to even notice the beauty motif as the starting line for the Old Testament redemption story as a major if not insurmountable obstacle for his whole edifice. If it can be shown that the beauty motif is also present in other 'redemption texts' of the Old Testament, the Westermann model of beauty will have to be abandoned. However, that calls for another investigation. ${ }^{28}$

\section{References}

Blass, F. \& Debrunner, A., 2001, Grammatik des neutestamentlichen Griechisch, 18. Aufl., Vandenhoeck \& Ruprecht, Göttingen.

Blum, E., 2002, 'Die literarische Verbindung von Erzvätern und Exodus: Ein Gespräch mit neueren Endredaktionshypothesen', in J.C. Gertz et al. (Hrsg.), Abschied vom Jahwisten: Die Komposition des Hexateuch in der jüngsten Diskussion, pp. 119156, BZAW 315, De Gruyter, Berlin.

Dell, K., 2010, 'Old Testament Theology in ecological focus', in S. Fischer \& M. Grohmann (eds.), Weisheit und Schöpfung, pp. 59-77, WAS 7, Peter Lang Verlag, Wien.

Elliott, M., 2009, 'Ästhetik', in O. Wischmeyer et al. (Hrsg.), Lexikon der Bibelhermeneutik: Begriffe - Methoden - Theorien - Konzepte, pp. 1-2, De Gruyter, Berlin.

Gerhards, M., 2006, Die Aussetzungsgeschichte des Mose: Literar- und traditionsgeschichtliche Untersuchungen zu einem Schlüsseltext des nichtpriesterschriftlichen Tetrateuch, WMANT 109, Neukirchener Verlag, Neukirchen-Vluyn.

Gertz, J.C., 2000, Tradition und Redaktion in der Exoduserzählung: Untersuchungen zur Endredaktion des Pentateuch, FRLANT 186, Vandenhoeck \& Ruprecht, Göttingen.

28.For instance, the beauty motif in stories of deliverance such as Judges 5, Zion Psalms on the beauty of the city as well as its deliverance, the beauty of God in the Book of Exodus (cf. Elliott 2009:1) and the Sinai narrative, human beauty in the books of Esther and Judith but also and especially where other aspects of Westermann's 'blessing' trajectory intersect with his 'redemption' category. I hope Westermann's 'blessing' trajectory intersect
to publish a wider study in the near future. 
Gesenius, W. \& Kautzsch, E., 1966, Gesenius' Hebrew grammar, 2nd English edn., Clarendon Press, Oxford.

Gestrich, R., 2008, Schönheit Gottes: Anstösse zu einer neuen Wahrnehmung, Lit Verlag, Berlin.

Gunkel, H., [1901] 1969, Genesis, 8. Aufl., Vandenhoeck \& Ruprecht, Göttingen.

Heinzle, J., 2007, 'Heldendichtung', in H. Fricke (Hrsg.), Reallexikon der deutschen Literaturwissenschaft, vol. 2., pp. 21-25, Walter de Gruyter, Berlin.

Johnson, L.T., 1992, The Acts of the Apostles, Sacta Pagina 5, Liturgical Press, Collegeville.

Loader, J.A., 2010 'Schön/Schönheit', in M. Bauks \& K. Koenen (Hrsg.), Das wissenschaftliche Bibellexikon, DBG, Stuttgart.

Michel, O., 1966, Der Brief an die Hebräer, 12. Aufl., KEKNT 13, Vandenhoeck \& Ruprecht, Göttingen.

Newman, B.M. \& Nida, E.A., 1972, A translator's handbook on the Acts of the Apostles, UBS, London.

Oeming, M., 2004, 'Schönheit II: Biblisch-theologisch', in H.D. Betz et al. (Hrsg.), Die Religion in Geschichte und Gegenwart, vol. 7, 4. Aufl., pp. 961-962, Mohr Siebeck, Tübingen.
Otto, E., 2000, 'Mose und das Gesetz: Die Mose-Figur als Gegenentwurf politischer Theologie zur neuassyrischen Königsideologie im 7. Jh. v.Chr.', in E. Otto (Hrsg.), Mose: Agypten und das Alte Testament, pp. 43-83, Stuttgarter Bibelstudien 189, Mose: Agypten und das Alte Testame
Katholisches Bibelwerk, Stuttgart.

Otto, E., 2006, Mose: Geschichte und Legende, Verlag C.H. Beck, München.

Särkiö, P., 1998, Exodus und Salomo: Erwägungen zur verdeckten Salomokritik anhand von Ex 1-2; 5; 14 und 32, SFEG 71, Vandenhoeck \& Ruprecht, Göttingen.

Schmid, H., 1986, Die Gestalt des Mose: Probleme alttestamentlicher Forschung unter Berücksichtigung der Pentateuchkrise, WBG, Darmstadt. (EdF 237).

Schmid, K.,1999, Erzväter und Exodus: Untersuchungen zur doppelten Begründung der Ursprünge Israels innerhalb der Geschichtsbücher des Alten Testaments, WMANT 81, Neukirchener Verlag, Neukirchen-Vluyn.

Westermann, C., [1968] 1992, Der Segen in der Bibel und im Handeln der Kirche, Chr. Kaiser Verlag, München.

Westermann, C., 1984, 'Das Schöne im Alten Testament', in C. Westermann (Hrsg.), Erträge der Forschung am Alten Testament. Gesammelte Studien, vol. 3., pp. 119137, Chr. Kaiser Verlag, München.

Williamson, R., 1989, Jews in the Hellenistic World: Philo, Cambridge Commentaries on the Writings of the Jewish and Christian World, vol. 1/2, Cambridge University Press, Cambridge. 